\title{
Enzyme mediated synthesis and characterization of silver nanoparticles using keratinase enzyme producing micro-organisms
}

\author{
B. Sudha, S. Sumathi and V. Swabna** \\ Department of Biochemistry, Biotechnology and Bioinformatics, Avinashilingam Institute for Home Science and Higher Education for \\ Women, Coimbatore-641043, TN, India \\ *Department of Biotechnology, St. Joseph's College (Autonomous), Tiruchirappalli-620002, TN, India
}

\begin{tabular}{|c|c|}
\hline Article Info & Abstract \\
\hline $\begin{array}{l}\text { Article history } \\
\text { Received } 4 \text { April } 2020 \\
\text { Revised } 22 \text { May } 2020 \\
\text { Accepted } 25 \text { May } 2020 \\
\text { Published online } 30 \text { June } 2020\end{array}$ & $\begin{array}{l}\text { Nanobiotechnology is a new multidisciplinary subject with the collaboration of biotechnology, } \\
\text { nanotechnology, chemical methodology and physical processing that depends on the nano-size objects } \\
\text { with their constitutional properties. Keratinolytic micro-organisms have an enormous role in poultry } \\
\text { waste degeneration and its biomodification is used in the production of fertilizer and animal meal. The } \\
\text { purpose of this study was to examine the competence of crude extracellular keratinase from bacterial }\end{array}$ \\
\hline $\begin{array}{l}\text { Keywords } \\
\text { Nanoparticles } \\
\text { Keratinase } \\
\text { FTIR } \\
\text { SEM } \\
\text { Antimicrobial activity }\end{array}$ & $\begin{array}{l}\text { strains for the production of nanoparticles and evaluation of its applications. Two keratinoltyic } \\
\text { bacterial strains were isolated from the peacock feather and were identified as Serratia plymuthica and } \\
\text { Serratia ficaria. Among these, Serratia ficaria showed high keratinolytic activity. Hence, it was used to } \\
\text { synthesize nanoparticles. Silver nanoparticles were synthesised and characterized by UV-visible } \\
\text { spectroscopy, FTIR, particle size analyser and SEM. The results indicate that the crude keratinase } \\
\text { enzyme produced by S. ficaria was found to be a good bioreductant. }\end{array}$ \\
\hline
\end{tabular}

\section{Introduction}

Production with the stabilisation of various types of nanoparticles was achieved by nanotechnology (Shaligram et al., 2009). Of these different types of nanoparticles, silver nanoparticles have verified to be the most effective with excellent antimicrobial potency (Anandaradje et al., 2020). Different kind of methods like laser irradiation, heating technique, radiolysis, ionizing radiation, microwave irradiation, pulsed laser ablation techniques and sonication were widely used for the synthesis of silver nanoparticles, which may expose dangerous effects to the environment. To avoid that, biological way of production is another method, which has shown a very promising solution to these problems. So, biological way of silver nanoparticles have been successfully synthesised using plant extracts (Guimarães et al., 2020); bacteria (Pourali and Yahyaei, 2016); yeast (Fernández et al., 2016) and fungi (Sanguiñedo et al., 2018). In this way, enzymes and phytocompound with reducing potentials have been responsible for the stabilisation and capping of nanoparticles (Hietzschold et al., 2019). This is achieved in an eco-friendly manner, which does not lead to the use of toxic chemicals. AgNPs have been used for so many purposes such as in the prescription of burns and dental works; in textile fabrics manufacturing; for waste water treatment; as sunscreen lotions and in the production of antimicrobial paint; non-linear optics; spectrally

Corresponding author: Dr. V. Swabna

Department of Biotechnology, St. Joseph's college (Autonomous), Tiruchirappalli-620002, TN, India

E-mail: swabna.vivek@gmail.com

Tel.: +91-9791506863

Copyright $@ 2020$ Ukaaz Publications. All rights reserved.

Email: ukaaz@yahoo.com; Website: www.ukaazpublications.com selective coating material; intercalation materials; optical receptors; catalysts; antibacterial and bio-labelling agents (Burdu'el et al., 2018). The purpose of this study was to examine the capability of crude extracellular keratinase produced by the bacterial strain that was isolated from peacock feather for the production of silver nanoparticles and evaluate its applications.

\section{Materials and Methods}

\subsection{Sample collection}

$100 \mathrm{~g}$ of peacock feathers were collected from the villages in Virallimalai, Tiruchirappalli district of Tamil Nadu. Half of the collected feathers were cut into pieces and dried for $24 \mathrm{~h}$. After that, feather powder was prepared by burning the peacock feather with ghee flame.

\subsection{Isolation of keratinase producing organism}

The bacterium used in this study was isolated by following the methods described by Lateef et al. (2015) with slight modifications.

The medium composition shown in Table 1.

Table 1: Medium composition

\begin{tabular}{|l|l|l|}
\hline S. No. & Components & Quantity (g/l) \\
\hline 1. & $\mathrm{NaNO}_{3}$ & 2 \\
2. & $\mathrm{NaCl}$ & 2 \\
3. & $\mathrm{KH}_{2} \mathrm{PO}_{4}$ & 2 \\
4. & $\mathrm{MgSO}_{4}$ & 0.05 \\
5. & $\mathrm{FeSO}_{4} \cdot 7 \mathrm{H}_{2} \mathrm{O}$ & 0.1 \\
6. & $\mathrm{CaCO}_{3}$ & 0.1 \\
7. & Feather powder & 10 \\
8. & Agar-agar & 20 \\
\hline
\end{tabular}


The piece of peacock feather was placed on the medium, and allowed for $24 \mathrm{~h}$ for the growth of keratinolytic bacterial strain around the peacock feather. Then the bacterial isolation was done by serial dilution and spread plate technique. The pure isolates were identified using biochemical identification $\mathrm{KB} 003 \mathrm{Hi} 25^{\mathrm{TM}}$ Enterobacteriaceae Identification kit.

\subsection{Keratinase production}

A loopful of pure culture was inoculated into a medium containing $1 \%$ keratin substrate (peacock feather powder used as substrate) with $0.2 \%$ yeast extract ( $\mathrm{pH} 7.5)$. The cultures were incubated at $37^{\circ} \mathrm{C}$ at $100 \mathrm{rpm}$ for $48 \mathrm{~h} .1 \mathrm{ml}$ of inoculum was inoculated into $50 \mathrm{ml}$ of flask containing liquid minimal medium, and the flasks were incubated at $37^{\circ} \mathrm{C}$ at $1000 \mathrm{rpm}$ for $120 \mathrm{~h}$. After the incubation, the flasks were taken out, and the broth was centrifuged at 5,000 rpm at $10^{\circ} \mathrm{C}$ for $20 \mathrm{~min}$, and the supernatant was considered as the crude extracellular keratinase (Lateef et al., 2015).

\subsection{Keratinase assay}

The keratinase activity was determined using the method of Cheng et al. (1995) with certain modifications. About $0.5 \mathrm{ml}$ of crude keratinase enzyme was mixed with $2 \mathrm{ml}$ of phosphate buffer ( $\mathrm{pH}$ 7.5 ) that contain $0.5 \mathrm{~g}$ of feather powder. A control was maintained with buffer and feather powder only. The reaction mixtures were incubated at $40^{\circ} \mathrm{C}$ for $3 \mathrm{~h}$ at $100 \mathrm{rpm} .2 \mathrm{ml}$ of $10 \%$ trichloro acetic acid (TCA) was added to the reaction mixtures to terminate the reaction. The reaction mixture was centrifuged at 5,000 rpm for $20 \mathrm{~min}$ at $37^{\circ} \mathrm{C}$. The supernatant was taken and the pellet was discarded. The release of protein was measured and converted into keratinase enzyme units $(1 \mathrm{U}=0.01$ absorbance increase for $1 \mathrm{~h}$ reaction time (Revathi et al., 2013).

\subsection{Synthesis and characterization of silver nanoparticle}

For the synthesis of silver nanoparticles (AgNPs), $50 \mathrm{ml}$ of $1 \mathrm{mM}$ $\mathrm{AgNO}_{3}$ was added to $1 \mathrm{ml}$ of crude keratinase enzyme and the mixture was incubated at dark for 48 hours. After the incubation, the formation of AgNPs using keratinase were observed by colour change from yellow to reddish brown color. Then the synthesized silver nanoparticles were collected through centrifugation at 10,000 rpm for $10 \mathrm{~min}$. The pellet was collected and dried at room temperature (Lateef et al., 2015).

According to Bhat et al. (2011), the synthesised silver nanoparticles were characterized by Fourier transform infrared (FTIR) spectroscopy, UV-Vis, SEM and Particle size analyser. The keratinase coupled AgNP solution was centrifuged at $10,000 \mathrm{rpm}$ for $20 \mathrm{~min}$. The sediment pellet was then dried at room temperature and the powder obtained was used for FTIR measurement. The scanning electron microscopy (SEM) micrograph was obtained for the structural confirmation of nanoparticles. The particle size analysis reflects the reaction of silver particles and also the activity towards agglomeration and settlement. A light source is introduced into the cell and the scattered light is collected and measured for the particle size. Biosynthesized AgNPs using keratinase is measured by diffuse light scattering method to analyse the particle size and their settlement.

\subsection{Antibacterial activity of synthesized silver nanoparticle}

The test bacteria were maintained in nutrient agar slants. The microbial cultures were sub cultured and the cultured strains were allowed to grow for two days and was stored at $5^{\circ} \mathrm{C}$. The test organisms were cultured in nutrient broth medium, incubated at $37^{\circ} \mathrm{C}$ for $24 \mathrm{~h}$. Antibacterial activity of the synthesised AgNPs was assessed using disc diffusion method as described by Thillaimaharami et al. (2013).

Whatman No. 1 filter paper was used as a paper disc. Test organisms were inoculated into $10 \mathrm{ml}$ of distilled water. It was used to prepare 10 fold dilution. The nutrient agar was poured and allowed to solidify. Then the organisms were spread over the plates containing medium. The paper discs were dipped into the silver nanoparticles solutions and placed on the plates that were inoculated with test organisms. However, the control was a set of paper disc with crude keratinase only.

After incubation at room temperature for $24 \mathrm{~h}$, the inhibition zone was measured. Presence of the zone of inhibition around the paper disc was considered as positive for antimicrobial activity (Lateef etal., 2015).

\section{Results}

3.1 Sample collection and preparation of feather powder

Peacock feather (Figure 1) were collected from Virallimalai, Trichy District, Tamil Nadu, India. Prepared feather powder was shown in Figure 2.

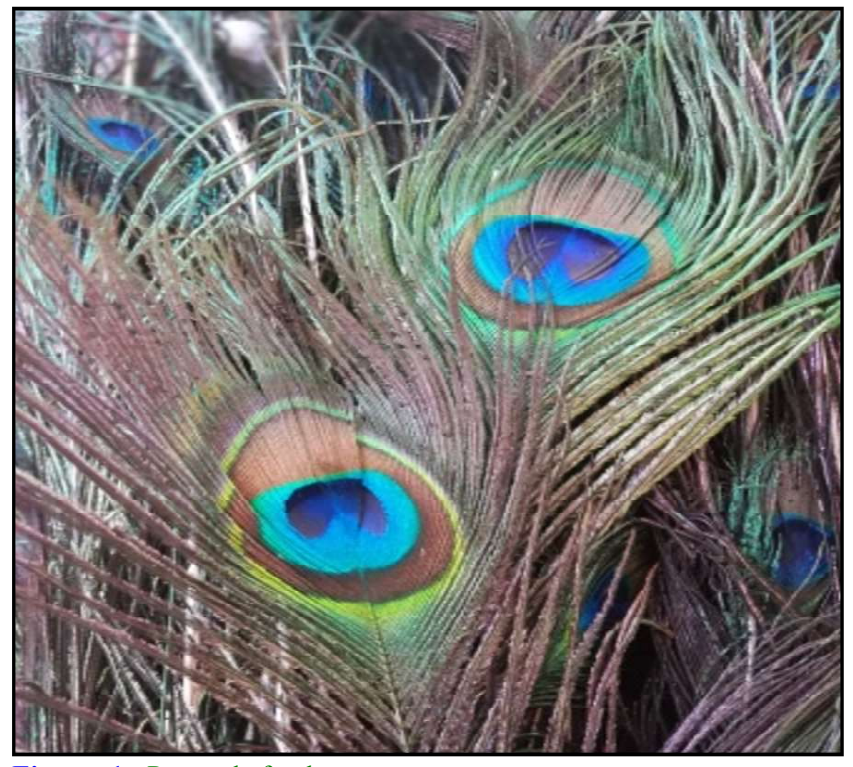

Figure 1: Peacock feather.

\subsection{Isolation of the bacterial species}

Two bacterial strains (Figure 3) were isolated from the peacock feather. The isolated bacterial strains were identified as (strain A) Serratia plymuthica and (strain B) Serratia ficaria by KB003 Hi25 $5^{\mathrm{TM}}$ Enterobacteriaceae Identification Kit. 


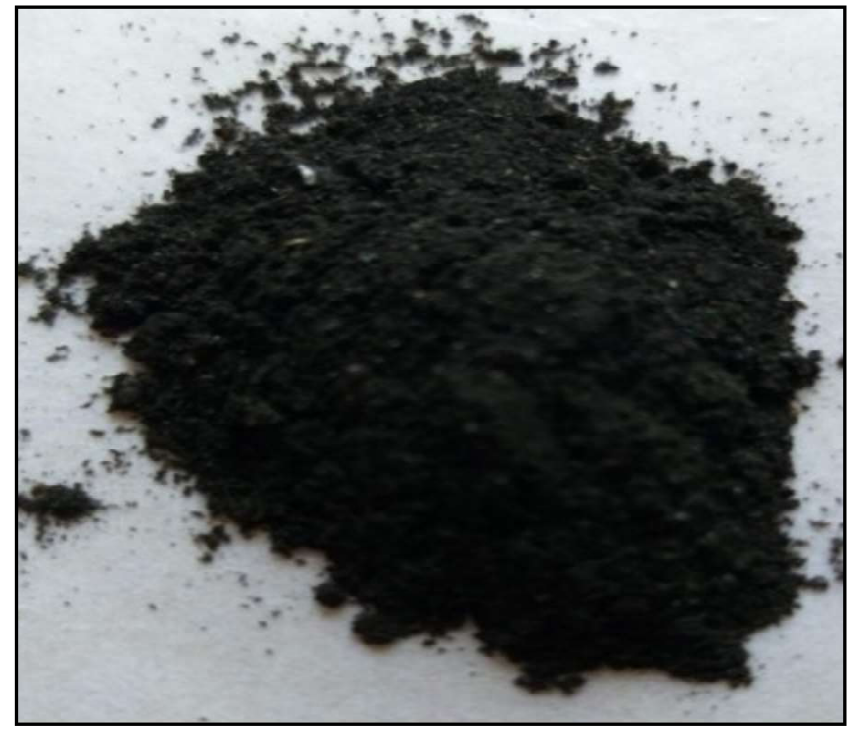

Figure 2: Feather powder.

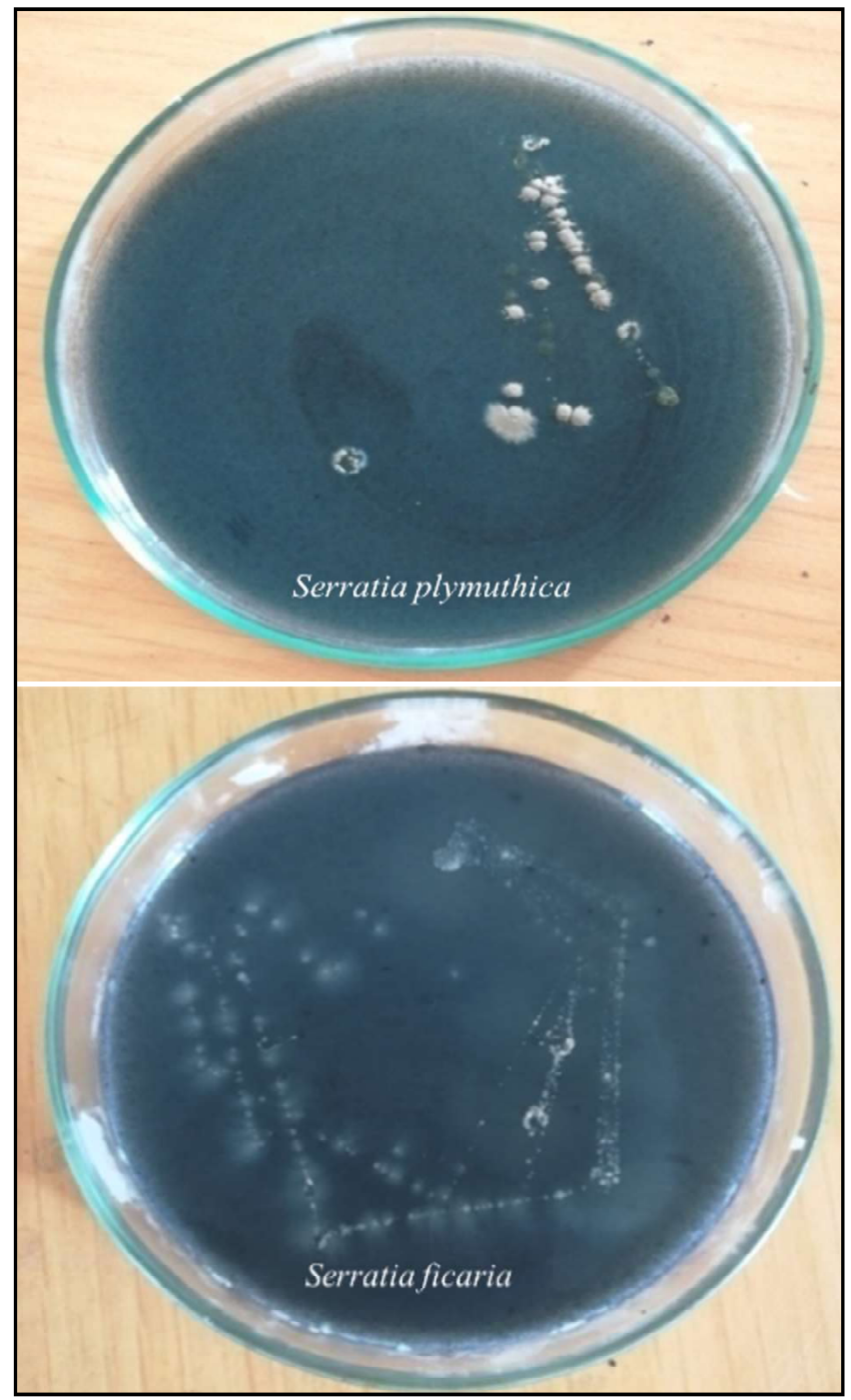

Figure 3: Bacterial isolates.

\subsection{Keratinolytic activity}

Both two strains $S$. plymuthica and $S$. ficaria produced crude keratinase enzyme. The enzymes were quantified as 2.01-5.6 $\mathrm{U} \mathrm{ml}^{-}$ ${ }^{1}$ in the $S$. plymuthica and $20.63-37.7 \mathrm{U} \mathrm{ml}^{-1}$ in the $S$. ficaria during $72 \mathrm{~h}$ of incubation using peacock feather powder as keratin substrate.

The enzyme activity reached a maximum of $5.6 \mathrm{U} \mathrm{ml}^{-1}$ for Serratia plymuthica and $37.7 \mathrm{U} \mathrm{ml}^{-1}$ for the Serratia ficaria at $72 \mathrm{~h}$ of cultivation.

Table 2: Keratinolytic activity of microbial strain

\begin{tabular}{|l|l|c|}
\hline S.No. & Strain & Keratinolytic activity \\
\hline 1. & Serratia plymuthica & $5.6 \pm 0.1$ \\
2. & Serratia ficaria & $37.7 \pm 0.5$ \\
\hline
\end{tabular}

Among these, S. ficaria showed maximum keratinolytic activity. Hence, S. ficaria producing keratinase enzyme was used for further studies.

\subsection{Biosynthesis of silver nanoparticles}

The formation of synthesised silver nanoparticles was monitored through visual observation of the change of colour, and measurement of the absorbance spectrum of the reaction mixture using UV-Visible spectrophotometer. In this study, silver nanoparticles were synthesized using white colored crude extracellular keratinase from S. ficaria.

Figure 4 shows the dark brown solution formed from the reaction of crude keratinase and $\mathrm{AgNO}_{3}$ solution after $48 \mathrm{~h}$ of reaction, while the $\mathrm{AgNO}_{3}$ solution in the control experiment remained unchanged. The dark brown solution formed is an indication of the synthesis of keratinase coupled AgNPs. The results of the present study showed that the crude keratinase from this strain can readily react with $\mathrm{AgNO}_{3}$ solution to form AgNPs.

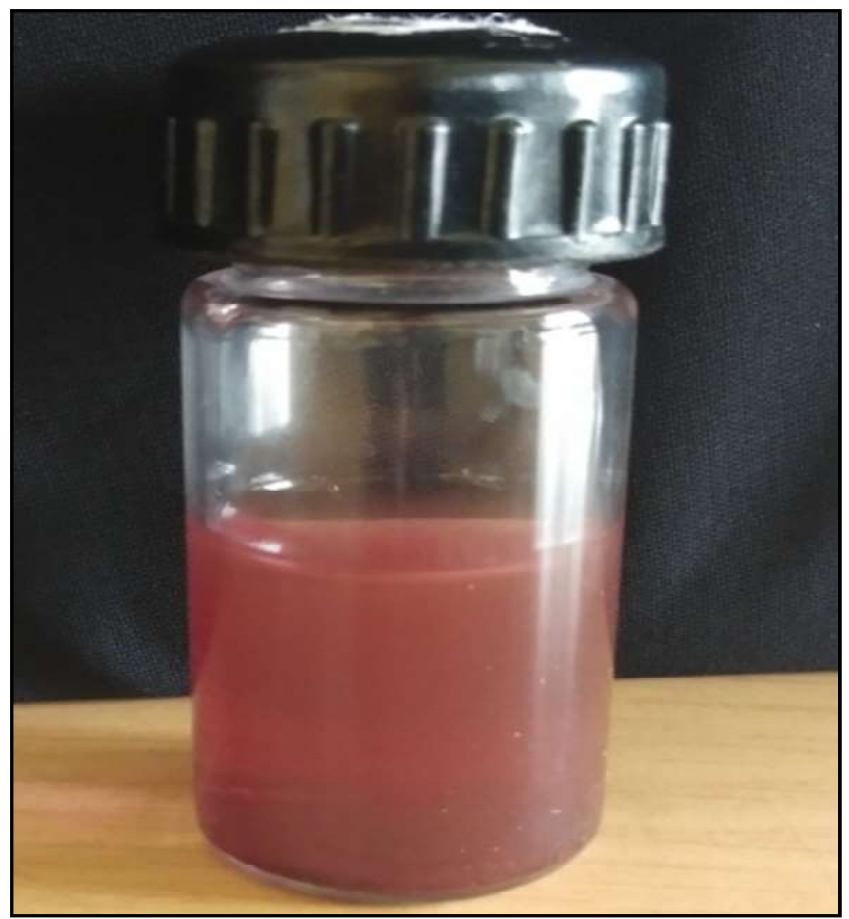

Figure 4: Silver nanoparticles solution. 


\subsection{Characterization of Nanoparticles}

Absorption spectroscopy was used to study the optical property of AgNPs. It is the method to observe the bioreduction of silver from silver nitrate to silver nanoparticle. Figure 5 shows the UV-
Visible spectra of the nanoparticles obtained by crude keratinase enzyme. The synthesised particle gave an absorption spectrum peaked at $470 \mathrm{~nm}$. This characteristic absorption peak justified the formation of AgNPs.

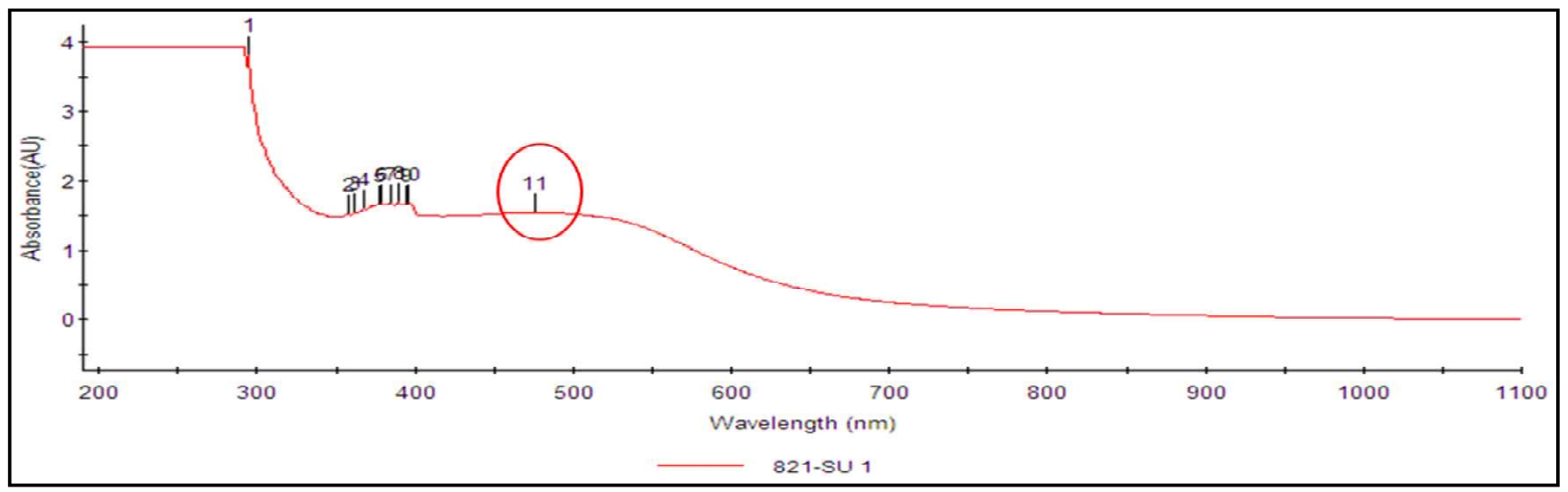

Figure 5: UV-Vis absorption spectrum of AgNPs using crude keratinase.

Functional groups present in the biomolecules are responsible for the silver bioreduction. Figure 6 shows the band intensities in different regions of the spectrum for AgNPs using keratinase. Different peak positions of synthesised silver nanoparticles exhibited bands at 3630.76, 3161.73, 2883.40, 1790.87, 1618.46, 1519.61, 1393.10, 1332.25, 1261.50, 1199.07, 739.43, 601.23, $556.45,472.97 \mathrm{~cm}^{-1}$. Peak position having spectra with marginal shifts point out the presence of the enzyme in the sample as a capping agent to the AgNPs. The bands at $3630.76 \mathrm{~cm}^{-1}$ is assigned as alcohol stretch, the band at $2883.40 \mathrm{~cm}^{-1}$ indicates alkanes, the band at $1519.61 \mathrm{~cm}^{-1}$ was recognized as amides, the band at 1393.10 $\mathrm{cm}^{-1}$ corresponds to alkanes, the band at $1332.25 \mathrm{~cm}^{-1}$ could be assigned to alkyl halides, the band at $1261.50 \mathrm{~cm}^{-1}$ and $1199.07 \mathrm{~cm}^{-1}$ indicates alcohols, the $472.97 \mathrm{~cm}^{-1}$ indicates alkyl halides.

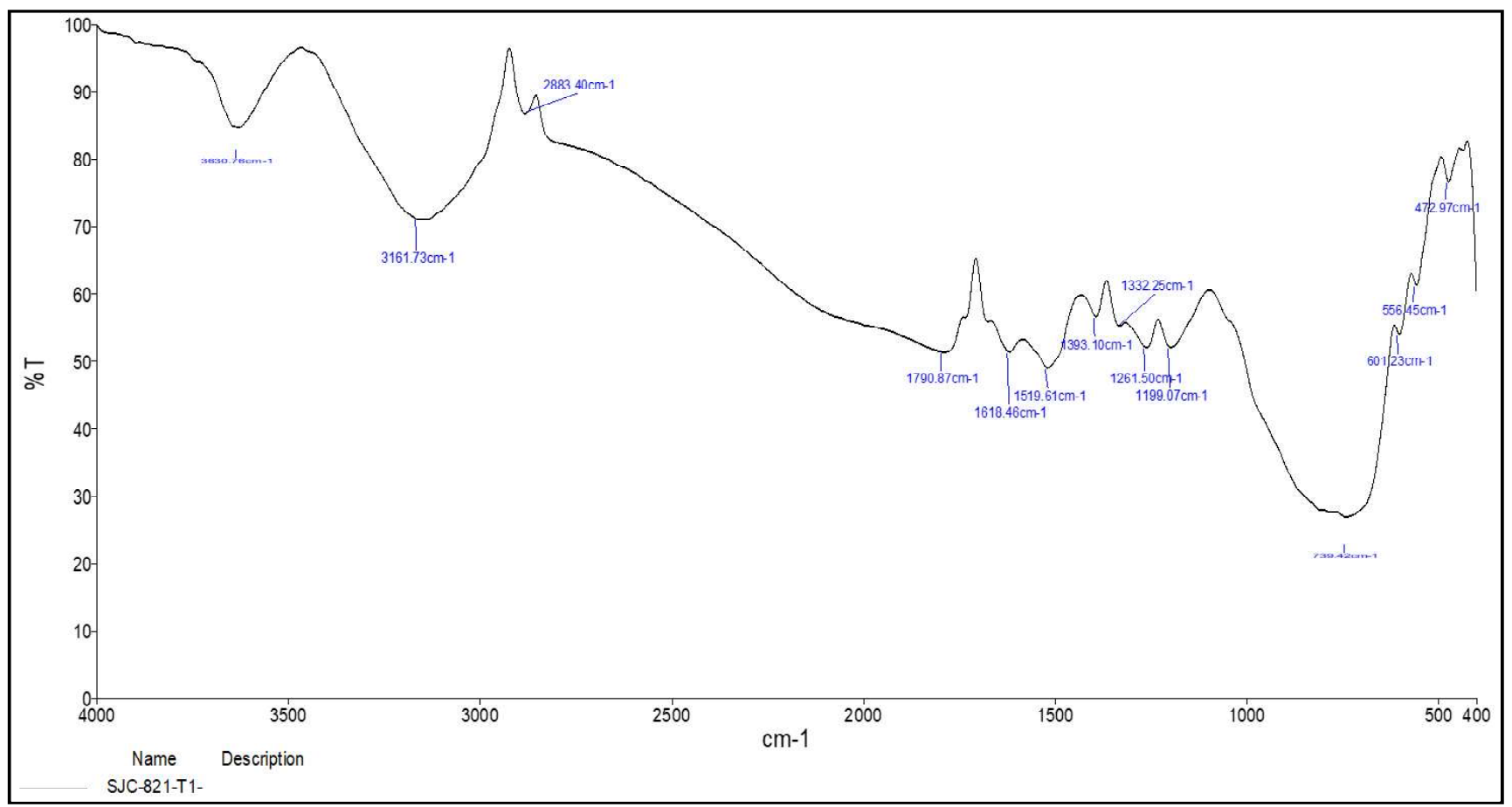

Figure 6: FTIR spectrum of keratinase coated silver nanoparticles.

The SEM micrograph of the keratinase coupled AgNPs is shown in (Figure 7). The morphology of silver nanoparticles was studied through the SEM analysis. Spherical shape of AgNPs has been reported, and the average size was $29 \mathrm{~nm}(14-44 \mathrm{~nm})$ by scanning electron microscope. 


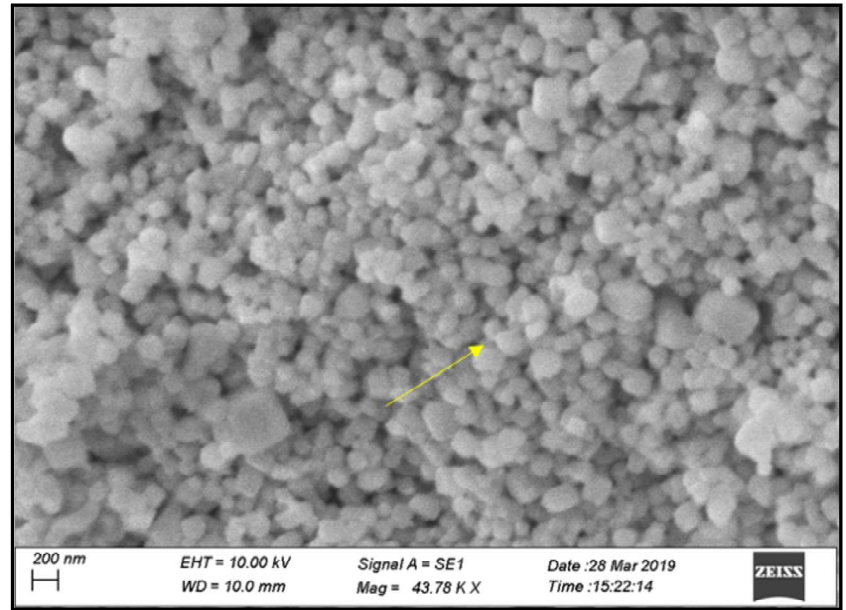

Figure 7: SEM image of keratinase coupled AgNPs using crude keratinase.

The Figure 8 shows size of the diameter of biosynthesised AgNPsat $56.8 \mathrm{~nm}$ by particle size analyser.

\subsection{Antibacterial activity}

Keratinase enzyme loaded silver nanoparticles showed higher antimicrobial activity against the bacterial species of Klebsiella oxytoca and Staphylococcus aureus compared to Entero bacterium amnigenus, Brevibacterium paucivorans, Staphylococcus lentus and Klebsiella pneumonia. The samples containing AgNPs showed good

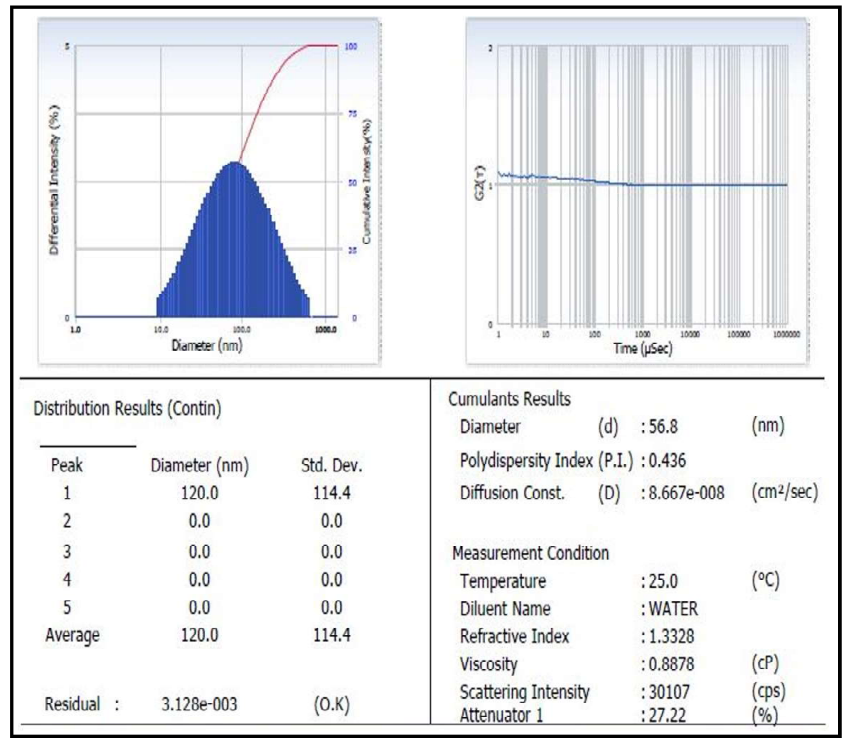

Figure 8: Particle size analysis of AgNPs.

inhibition zone. Figure 9 shows the zone of inhibition obtained against clinical pathogens. The zone of clearance was compared with the effects of respective standard antibiotics. Table 3 shows the antibacterial activity against the pathogens. As per the result of this study, a good inhibition activity was observed by silver nanoparticles using keratinase enzyme than the standard antibiotics.

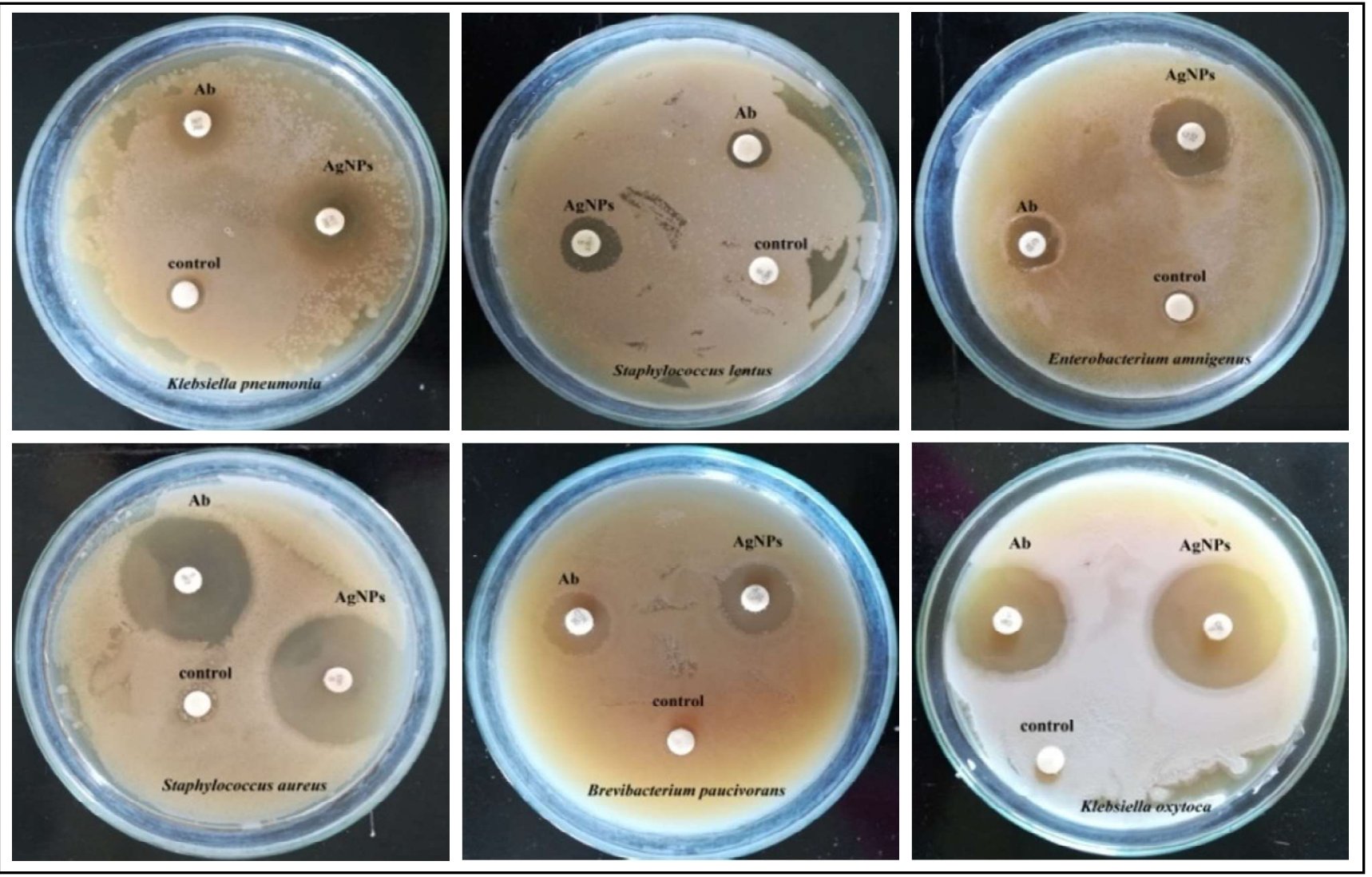

Figure 9: Antibacterial activity of AgNPs. 
Table 3: Inhibition zone of AgNPs using keratinase and standard antibiotis

\begin{tabular}{|l|l|l|l|l|}
\hline S.No. & Organism name & Inhibitory zone $\mathbf{( m m )}$ & Antibiotics (Standard) & Inhibitory zone $(\mathbf{m m})$ \\
\hline 1. & Klebsiella pneumonia & $20 \pm 0.4$ & Nitrofurantoin & $14 \pm 0.01$ \\
2. & Staphylococcus lentus & $15 \pm 0.21$ & Methicillin & $05 \pm 0.23$ \\
3. & Enterobacteriumamnigenus & $21 \pm 0.1$ & Chloramphenicol & $16 \pm 0.3$ \\
4. & Staphylococcus aureus & $35 \pm 0.02$ & Ciprofloxacin & $32 \pm 0.1$ \\
5. & Brevibacteriumpaucivorans & $17 \pm 0.26$ & Ceftriaxone & $15 \pm 0.05$ \\
6. & Klebsiellaoxytoca & $33 \pm 0.05$ & Ciprofloxacin & $29 \pm 0.14$ \\
\hline
\end{tabular}

\section{Discussion}

Saarela et al. (2017) isolated 122 keratinolytic isolates from birds nest. Agrahari and Wadhwa (2010) identified that bacterial strains B. megaterium SN1, B. thuringenesis SN2, B. pumilis from chicken feather dumping site. Like that, we identified S. plymuthica and $S$. ficaria. Our findings of keratinolytic activity of microbes associated with Lateef et al. (2010) and Kalishwaralal et al. (2008).

There are limited reports for the production of nanoparticles using keratinase (Revathi et al., 2013). Silver ion reduction by the enzyme gave a colour to the silver nanoparticles. Based on the progress of silver ion, the colour intensity was increased and when the reaction is completed, it becomes stable. Silver nanoparticle colour was reported byTripathy et al. (2010), Roopan et al. (2013) and Nahar et al. (2020) which may be attributed because of the variations in the biomolecules composition. Kalishwaralal et al. (2008) reported that brown colour AgNPs synthesised from culture supernatant of Bacillus licheniformis. Revathi et al. (2013) revealed that the synthesis of dark brown coloured AgNPs from crude keratinase after $72 \mathrm{~h}$ of incubation. Because of the excitation of surface plasmon vibrations in silver nanoparticles, colour formation was observed by Rai et al. (2009). These results were similar to our recent findings.

UV-Visible absorption spectrum examined the structural changes and complex formation of synthesised nanopaticles. Bands of surface plasmon resonance play a major role in size, shape and morphology was reported by Pant et al. (2013). Absorbance in the range of $400 \mathrm{~nm}$ to $450 \mathrm{~nm}$ has been used to affirm the silver reduction to metallic silver (Srivastava et al., 2011 and Tripathy et al., 2010).

Measurements of Fourier Transform Infrared Spectroscopy were executed to find the feasible biomoleculs that are responsible for the capping, reduction and potent stabilization of AgNPs (Durán et al. 2005). The observed peaks are principally associated due to presence of some secondary metabolites suggested by Pant et al. (2013), Roopan et al. (2013). Size variation, size distribution and capacity for aggregation, stabilities were observed by SEM analysis Fatema et al. (2019). The existence of nanocrsytalline image were also disclosed by Nahar et al. (2020) and Lateef et al. (2015). These properties may influence the activity of AgNPs especially antimicrobial activity. A study on AgNPs by silver nitrate solution with the culture supernatant of $K$. pneumoniae has also been reported that particle size range was in $52.5 \mathrm{~nm}$ (Durán et al. 2005). Synthesis of silver nanoparticles using Morganella sp., reported that approx. $20 \mathrm{~nm}$ size of spherical nanoparticles (Fatema et al. 2019). Our present findings about the characterization of keratinase coated silver nanoparticles similar to these results.
The AgNPs disrupts the cell membrane and releases the reactive oxygen species that result in damage of protein and DNA. In the present study, keratinase enzyme - NPs were effective against S. auerus and Klebsiella oxytoca. So many theories like permeability of cell membrane alteration (Shaligram et al., 2009), leakage of membrane protein and lipopolysaccharide (Klefenz, 2004), production of free radical (Kim et al. 2007), collapse of membrane potential due to proton motive force dissipation (Lok et al., 2006) were reported about antibacterial action of AgNPs. Furthermore, silver nanoparticles have high surface area, volume ratio that corresponds to effective antimicrobial action as compared with huge silver metal Lateef et al. (2015). Due to close attachment of the nanoparticles surface with the microbial cells determines that the antimicrobial property was to be size dependent Bhat et al. (2011). Like that, our results of the recent study cleared that the keratinase loaded silver nanoparticles showed good inhibition activity against the microbes. Hence, the remarkable antibacterial property reported by the AgNPs proved that it could either be combined with antibiotic drugs or used directly as drugs for some topical applications.

\section{Conclusion}

The results of the present study showed that the two bacterial isolates from the peacock feather was identified as S. plymuthica and $S$. ficaria. Among these, the $S$. ficaria showed maximum keratinolytic activity, hence it can be exploited for the synthesis of silver nanoparticles. Biosynthesis of keratinase enzyme loaded AgNPs was successfully done by $\mathrm{AgNO}_{3}$ treated with crude keratinase enzyme. This technique revealed that crude keratinase enzyme can be used as an active stabilizing and capping agent for the silver nanoparticle synthesis. This is a very simple, inexpensive, method for the production of nanoparticles. It shows good antibacterial activity. Therefore, the stabilised and uniform shaped AgNPs obtained from this easy and ecofriendly method of synthesis could be used in drug formulation for topical applications and also for various biotechnological applications.

\section{Acknowledgements}

Authors are thankful to St. Joseph's College (Autonomous), Tiruchirappalli, Tamil Nadu, India for providing infrastructure facilities for completion of this study.

\section{Conflict of interest}

The authors declare that there are no conflicts of interest in the course of conducting the research. All the authors had final decision regarding the manuscript and decision to submit the findings for publication. 


\section{References}

Anandaradje, A.; Meyappan, V.; Kumar, I. and Sakthivel, N. (2020). Microbial synthesis of silver nanoparticles and their biological potential. In Nanoparticles in Medicine, pp:99-133.

Agrahari, S., and Wadhwa, N. (2010). Degradation of chicken feather a poultry waste product by keratinolytic bacteria isolated from dumping site at Ghazipur poultry processing plant. Int. J. Poult. Sci., 9(5):482-489.

Bhat, R.; Deshpande, R.; Ganachari, S.V.; Huh, D.S. and Venkataraman, A. (2011). Photo-irradiated biosynthesis of silver nanoparticles using edible mushroom Pleurotus florida and their antibacterial activity studies. Bioinorganic Chemistry and Applications.

Burdu'el, A.C.; Gherasim, O.; Grumezescu, A.M.; Mogoantă, L.; Ficai, A. and Andronescu, E. (2018). Biomedical applications of silver nanoparticles: An up-to-date overview. Nanomaterials, 8(9):681.

Cheng, S.W.; Hu, H.M.; Shen, S.W.; Takagi, H.; Asano, M. and Tsai, Y.C. (1995). Production and characterization of keratinase of a feather-degrading Bacillus licheniformis PWD-1. Bioscience, Biotechnology and Biochemistry, 59(12):2239-2243.

Durán, N.; Marcato, P.D.; Alves, O.L.; De Souza, G.I. and Esposito, E. (2005). Mechanistic aspects of biosynthesis of silver nanoparticles by several Fusarium oxysporum strains. Journal of Nanobiotechnology, 3(1):8.

Fatema, S.; Shirsat, M.; Farooqui, M. and Pathan, M.A. (2019). Biosynthesis of silver nanoparticle using aqueous extract of Saraca asoca leaves, its characterization and antimicrobial activity. International Journal of Nano Dimension, 10(2):163-168.

Fernández, J.G., Fernández-Baldo, M.A., Berni, E., Camí, G., Durán, N., Raba, J. and Sanz, M.I. (2016). Production of silver nanoparticles using yeasts and evaluation of their antifungal activity against phytopathogenic fungi. Process Biochemistry, 51(9):1306-1313.

Guimarães, M.L.; da Silva, F.A.G.; da Costa, M.M. and de Oliveira, H.P. (2020). Green synthesis of silver nanoparticles using Ziziphus joazeiro leaf extract for production of antibacterial agents. Applied Nanoscience, 10(4):1073-1081.

Hietzschold, S.; Walter, A.; Davis, C.; Taylor, A.A. and Sepunaru, L. (2019). Does nitrate reductase play a role in silver nanoparticle synthesis? Evidence for NADPH as the sole reducing agent. ACS Sustainable Chemistry and Engineering, 7(9):8070-8076.

Kalishwaralal, K.; Deepak, V.; Ramkumarpandian, S.; Nellaiah, H. and Sangiliyandi, G. (2008). Extracellular biosynthesis of silver nanoparticles by the culture supernatant of Bacillus licheniformis. Materials Letters, 62(29):4411-4413.

Kim, J.S.; Kuk, E.; Yu, K.N.; Kim, J.H.; Park, S.J.; Lee, H.J.; Kim, S.H.; Park, Y.K.; Park, Y.H.; Hwang, C.Y. and Kim, Y.K. (2007). Antimicrobial effects of silver nanoparticles. Nanomedicine: Nanotechnology, Biology and Medicine, 3(1):95-101.

Klefenz, H., (2004). Nanobiotechnology: from molecules to systems. Engineering in Life Sciences, 4(3):211-218.

Lateef, A., Adelere, I.A., Gueguim-Kana, E.B., Asafa, T.B. and Beukes, L.S. (2015). Green synthesis of silver nanoparticles using keratinase obtained from a strain of Bacillus safensis LAU 13. International Nano Letters, 5(1):29-35.
Lateef, A., Oloke, J.K., Kana, E.G., Sobowale, B.O., Ajao, S.O. and Bello, B.Y. (2010). Keratinolytic activities of a new feather-degrading isolate of Bacillus cereus LAU 08 isolated from Nigerian soil. International Biodeterioration and Biodegradation, 64(2):162-165.

Lok, C.N., Ho, C.M., Chen, R., He, Q.Y., Yu, W.Y., Sun, H., Tam, P.K.H., Chiu, J.F. and Che, C.M. (2006). Proteomic analysis of the mode of antibacterial action of silver nanoparticles. Journal of Pproteome Research, 5(4):916-924.

Nahar, K., Aziz, S., Bashar, M., Haque, M. and Al-Reza, S.M. (2020). Synthesis and characterization of Silver nanoparticles from Cinnamomum tamala leaf extract and its antibacterial potential. International Journal of Nano Dimension, 11(1):88-98.

Pant, G., Nayak, N. and Prasuna, R.G. (2013). Enhancement of antidandruff activity of shampoo by biosynthesized silver nanoparticles from Solanum trilobatum plant leaf. Applied Nanoscience, 3(5):431-439.

Pourali, P. and Yahyaei, B. (2016). Biological production of silver nanoparticles by soil isolated bacteria and preliminary study of their cytotoxicity and cutaneous wound healing efficiency in rat. Journal of Trace Elements in Medicine and Biology, 34:22-31.

Rai, M., Yadav, A. and Gade, A. (2009). Silver nanoparticles as a new generation of antimicrobials. Biotechnology Advances, 27(1):76-83.

Revathi, K., Shaifali, S., Mohd, A.K. and Suneetha, V. (2013). A potential strain of keratinolytic bacteria VIT RSAS2 from katpadi and its pharmacological benefits. Int. J. Pharm. Sci. Res., 20(2):89-92.

Roopan, S.M., Madhumitha, G., Rahuman, A.A., Kamaraj, C., Bharathi, A. and Surendra, T.V. (2013). Low-cost and eco-friendly phyto-synthesis of silver nanoparticles using Cocosnucifera coir extract and its larvicidal activity. Industrial Crops and Products, 43:631-635.

Saarela, M., Berlin, M., Nygren, H., Lahtinen, P., Honkapää, K., Lantto, R. and Maukonen, J. (2017). Characterization of feather-degrading bacterial populations from birds' nests-Potential strains for biomass production for animal feed. International Biodeterioration and Biodegradation, 123:262-268.

Sanguiñedo, P., Fratila, R.M., Estevez, M.B., de la Fuente, J.M., Grazú, V. and Alborés, S. (2018). Extracellular biosynthesis of silver nanoparticles using fungi and their antibacterial activity. Nano Biomedicine and Engineering, 10(2):156-164.

Shaligram, N.S., Bule, M., Bhambure, R., Singhal, R.S., Singh, S.K., Szakacs, G. and Pandey, A. (2009). Biosynthesis of silver nanoparticles using aqueous extract from the compactin producing fungal strain. Process Biochemistry, 44(8):939-943.

Srivastava, A.A., Kulkarni, A.P., Harpale, P.M. and Zunjarrao, R.S. (2011). Plant mediated synthesis of silver nanoparticles using a bryophyte: Fissidens minutus and its anti-microbial activity. International Journal of Engineering Science and Technology, 3(12).

Thillaimaharani, K.A., Sharmila, K., Thangaraju, P., Karthick, M. and Kalaiselvam, M. (2013). Studies on antimicrobial and antioxidant properties of oyster mushroom Pleurotusflorida. International Journal of Pharmaceutical Sciences and Research, 4(4):1540.

Tripathy, A., Raichur, A.M., Chandrasekaran, N., Prathna, T.C. and Mukherjee, A. (2010). Process variables in biomimetic synthesis of silver nanoparticles by aqueous extract of Azadirachta indica (Neem) leaves. Journal of Nanoparticle Research, 12(1):237-246.

Citation: B. Sudha, S. Sumathi and V. Swabna (2020). Enzyme mediated synthesis and characterization of silver nanoparticles using keratinase enzyme producing micro-organisms. Ann. Phytomed., 9(1):147-153. http://dx.doi.org/10.21276/ap.2020.9.1.19 